\title{
Immunolocalization and protein expression of the $\alpha$ subunit of the large-conductance calcium-activated potassium channel in human myometrium
}

\author{
B. Chanrachakul ${ }^{1}$, B. Matharoo-Ball ${ }^{1}$, A. Turner ${ }^{1}$, G. Robinson ${ }^{2}$, \\ F. Broughton-Pipkin ${ }^{2}$, S. Arulkumaran ${ }^{3}$ and R. N. Khan ${ }^{1 *}$ \\ ${ }^{1}$ Academic Division of Obstetrics and Gynaecology, Derby City General Hospital, University of \\ Nottingham, Derby DE22 3NE, UK; ${ }^{2}$ Academic Division of Obstetrics and Gynaecology, \\ Queen's Medical Centre, University of Nottingham, Nottingham NG7 2UH, UK; and ${ }^{3}$ Academic \\ Division of Obstetrics and Gynaecology, St George's Hospital Medical School, \\ University of London, London SW17 ORE, UK
}

Large-conductance calcium-activated potassium $\left(\mathrm{BK}_{\mathrm{Ca}}\right)$ channels play an important role in the control of myometrial excitability. The aim of the present study was to determine the localization and protein expression of the $\alpha$ subunit of $\mathrm{BK}_{\mathrm{Ca}}$ channels in the pregnant and parturient human uterus. An anti- $\alpha \mathrm{BK}_{\mathrm{Ca}}$ channel monoclonal antibody (anti- $\alpha_{995-1113}$ ) was used to localize and quantitate immunoreactive $\mathrm{BK}_{\mathrm{Ca}}$ channel protein in myometrium of singleton term pregnant women undergoing either elective $(n=26)$ or emergency Caesarean section following the onset of spontaneous labour $(n=25)$. Data are presented as medians (interquartile range). Differences between groups were analysed using the Mann-Whitney $U$ test. Immunohistochemistry studies localized the $\alpha$ subunit of the $\mathrm{BK}_{\mathrm{Ca}}$ channel to the plasma membrane and the cytosol of myometrial cells with similar reaction end product in pregnant women who were or were not undergoing labour. Expression of this subunit, observed as a $125 \mathrm{kDa}$ band in western blots, was significantly higher in pregnant women who were not undergoing labour $(30.6 \%(20.3,43.9))$ than in those who were undergoing labour $(15.7 \%(11.3,22.4)$; $\boldsymbol{P}<0.01)$. Reduced $\mathrm{BK}_{\mathrm{Ca}} \alpha$ subunit expression in pregnant women during labour may underlie the initiation of uterine contractility during parturition.

\section{Introduction}

Although much research has been performed in an attempt to identify novel approaches to prevent preterm delivery, preterm labour is still the major cause of perinatal mortality and morbidity (American College of Obstetricians and Gynecologists, 2001). Ritodrine and other beta-2 $\left(\beta_{2}\right)$ agonists are used widely as the main treatment for preterm labour, but their benefits are limited as these drugs are effective only for a short period (Jeyabalan and Caritis, 2002). Other tocolytics, such as magnesium sulphate, calcium channel blockers and prostaglandin synthase inhibitors, are also not very effective and may be associated with maternal and fetal adverse effects (Jeyabalan and Caritis, 2002).

Recent data have shown that large-conductance calcium-activated potassium $\left(\mathrm{BK}_{\mathrm{Ca}}\right)$ channels, which are abundant in smooth muscle, are involved in mediating

*Correspondence

Email: raheela.khan@nottingham.ac.uk uterine relaxation (Anwer et al., 1993; Khan et al., 1998). $\mathrm{BK}_{\mathrm{Ca}}$ channels are activated in response to increased intracellular calcium and play an important role in counteracting cellular depolarization. However, the relationship between these channels and uterine contraction is still not clear. $\mathrm{BK}_{\mathrm{Ca}}$ channels are present at high density in both pregnant and non-pregnant human myometrium (Anwer et al., 1993; Erulkar et al., 1993; Perez et al., 1993; Khan et al., 1993, 1997). Although the presence of these channels in the uterus is established, direct immunolocalization in the human myometrium during parturition has not yet been shown. The objectives of the present study were to investigate the cellular localization and distribution of the $\alpha$ subunit (which is the pore-forming part of the $\mathrm{BK}_{\mathrm{Ca}}$ channel) using a monoclonal antibody to the $\alpha$ subunit of the $\mathrm{BK}_{\mathrm{Ca}}$ channel in human myometrium before and during parturition. Protein expression of the $\alpha$ subunit of the $\mathrm{BK}_{\mathrm{Ca}}$ channel was also examined by western blotting to establish whether there is differential expression of this channel between pregnant women at term who are and are not undergoing labour. 


\section{Materials and Methods}

The present study was carried out at the Academic Division of Obstetrics and Gynaecology, University of Nottingham, Derby City General Hospital. Ethical approval was granted by the Southern Derbyshire Ethics Committee. Two groups of women were recruited for this study: (1) singleton term pregnant women (gestational age $\geqslant 37$ weeks) undergoing elective Caesarean section before the onset of labour $(n=26)$ and (2) singleton term pregnant women undergoing emergency Caesarean section after spontaneous labour (cervical dilatation $\geqslant 3 \mathrm{~cm} ; n=25$ ). Written informed consent was obtained from each participant. The myometrial biopsy was taken from the mid-upper margin of the lower uterine incision in women undergoing Caesarean section. Samples were then divided into two: one part was used for immunostaining and the other for western blotting. For immunohistochemistry, samples were fixed in $10 \%(\mathrm{v} / \mathrm{v})$ formol saline overnight at $4{ }^{\circ} \mathrm{C}$ and then processed to $51^{\circ} \mathrm{C}$ melting point paraffin wax. Samples for western blotting were snap-frozen in liquid nitrogen and stored at $-80^{\circ} \mathrm{C}$ until required.

\section{Immunohistochemistry}

Paraffin wax-embedded sections (of $4 \mu \mathrm{m}$ thickness) were deparaffinized in xylene and rehydrated in a graded alcohol series. Antigen retrieval to unmask epitopes was performed in a microwave oven at $800 \mathrm{~W}$ for $15 \mathrm{~min}$ in $10 \mathrm{mmol}$ citrate buffer $\mathrm{I}^{-1}(\mathrm{pH} \mathrm{6})$. Endogenous peroxidase activity was quenched using $0.6 \%(\mathrm{v} / \mathrm{v})$ hydrogen peroxide $\left(\mathrm{H}_{2} \mathrm{O}_{2}\right)$ in methanol and non-specific background staining was prevented by incubation with non-immune horse serum. Excess serum was blotted after which tissue sections were incubated with anti- $\alpha_{995-1113}$ primary antibody at a dilution of $1: 50$ at $4{ }^{\circ} \mathrm{C}$ overnight followed by $1 \mathrm{~h}$ at room temperature $\left(22-25^{\circ} \mathrm{C}\right)$. The mouse monoclonal antibody anti- $\alpha_{995-1113}$ recognizes amino acid residues 995-1113 at the C terminus of the $\alpha$ subunit of the $\mathrm{BK}_{\mathrm{Ca}}$ channel (Transduction Laboratories, Oxford, KY). A normal mouse immunoglobulin IgG (DAKO, Glostrup) at the same dilution as the primary antibody was used as a negative control, whereas an anti- $\alpha$-actin monoclonal antibody (DAKO) was used as a positive control. Tissue sections were subsequently washed with Tris-buffered saline (TBS; $0.15 \mathrm{~mol} \mathrm{NaCl}$ $\mathrm{I}^{-1}, 0.05 \mathrm{~mol}_{\text {Tris I }}^{-1}, \mathrm{pH}$ 7.6) and incubated with biotinylated horse anti-mouse antibody (Vector Laboratories, Peterborough), then by avidin-biotinylated horseradish peroxidase reagent (Vector Laboratories). The antigen was localized by 3,3'-diaminobenzidine tetrahydrochloride (DAB; Vector Laboratories) and counterstained with Harris' haematoxylin (Nustain, Nottingham). The slides were subsequently dehydrated in a graded alcohol series, cleared in xylene and mounted in DPX. Sections were viewed under a Leica DMRB microscope using transmitted light illumination and photographs were taken at appropriate magnifications using an attached Leica Wild MPS48 modular photomicrographic system and Fujichrome 100 ASA colour reversal film.

\section{Western blot analysis}

Myometrial tissues $(300 \mathrm{mg}$ ) were homogenized on ice in homogenization buffer $\left(25 \mathrm{mmol}\right.$ Tris- $\mathrm{HCl} \mathrm{I}^{-1}$

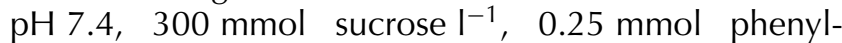
methylsulphonyl fluoride (PMSF) $\mathrm{I}^{-1}, 1.0 \mathrm{mmol}$ EGTA $\mathrm{I}^{-1}, 0.1 \%(\mathrm{v} / \mathrm{v})$ Tween 20 and centrifuged at $1000 \mathrm{~g}$ for $10 \mathrm{~min}$ at $4^{\circ} \mathrm{C}$. The resulting supernatant was centrifuged at $100000 \mathrm{~g}$ for $1 \mathrm{~h}$ at $4^{\circ} \mathrm{C}$ to pellet the cell membranes. The crude membrane pellet was resuspended in homogenization buffer and the total protein concentration determined using the bicinchoninic acid (BCA) method; the pellet was then stored at $-80^{\circ} \mathrm{C}$. Equal amounts of myometrial membrane proteins $(60 \mu \mathrm{g})$ were loaded on to and resolved by SDS-PAGE (Protean III, Bio-Rad, Hemel Hempstead) on $10 \%(\mathrm{w} / \mathrm{v})$ gels. Proteins were then transferred by electroblotting on to nitrocellulose paper. At this point, blots were stained with Ponceau $S$ to check for equal loading and transfer of proteins. After blocking with $5 \%(\mathrm{w} / \mathrm{v})$ non-fat milk powder (Marvel) and $0.1 \%(\mathrm{v} / \mathrm{v})$ Tween in TBS, blots were incubated with anti- $\alpha_{995-1113}$ antibody at a dilution of 1:750 overnight at $4{ }^{\circ} \mathrm{C}$, washed repeatedly and then incubated with alkaline phosphatase-conjugated secondary antibody at room temperature for $2 \mathrm{~h}$. After further washing, blots were incubated with Immun-STAR reagent (Bio-Rad) and protein was quantitated by imaging densitometry (ChemiDoc, Bio-Rad). The specificity of the anti- $\alpha_{995-1113}$ channel antibody for its antigen was tested by incubating it with primary antibody preadsorbed with $\alpha$ subunit $\mathrm{BK}_{\mathrm{Ca}}$ channel blocking peptide (Alomone Labs, Jerusalem) at fivefold excess. The antibody with which this peptide is supplied recognizes residues 1098-1196 at the C terminus of the $\alpha$ subunit, sharing 15 amino acids with anti- $\alpha_{995-1113}$ antibody. A crude membrane preparation was prepared from the brain of a non-pregnant female rat (as described for myometrium) and served as a $\mathrm{BK}_{\mathrm{Ca}}$ channel-positive control (Wanner et al., 1999) and internal reference against which the signal intensity of myometrial $\mathrm{BK}_{\mathrm{Ca}}$ channel $\alpha$ subunit protein was compared.

\section{Statistical analysis}

On the basis of a pilot study, the standard deviation of expression of the $\alpha$ subunit of the $\mathrm{BK}_{\mathrm{Ca}}$ channel was $17.5 \%$ and the mean difference of the $\alpha$ subunit of $\mathrm{BK}_{\mathrm{Ca}}$ channel between non-labouring and labouring women was $14.5 \%$. Twenty-four participants in each group were required for this study to have $80 \%$ power at a type I error of 0.05 .

The signal intensity of $\mathrm{BK}_{\mathrm{Ca}}$ channel $\alpha$ subunit protein was expressed as a percentage of the $\alpha$ subunit signal of rat brain membrane on the same blot. Statistical 

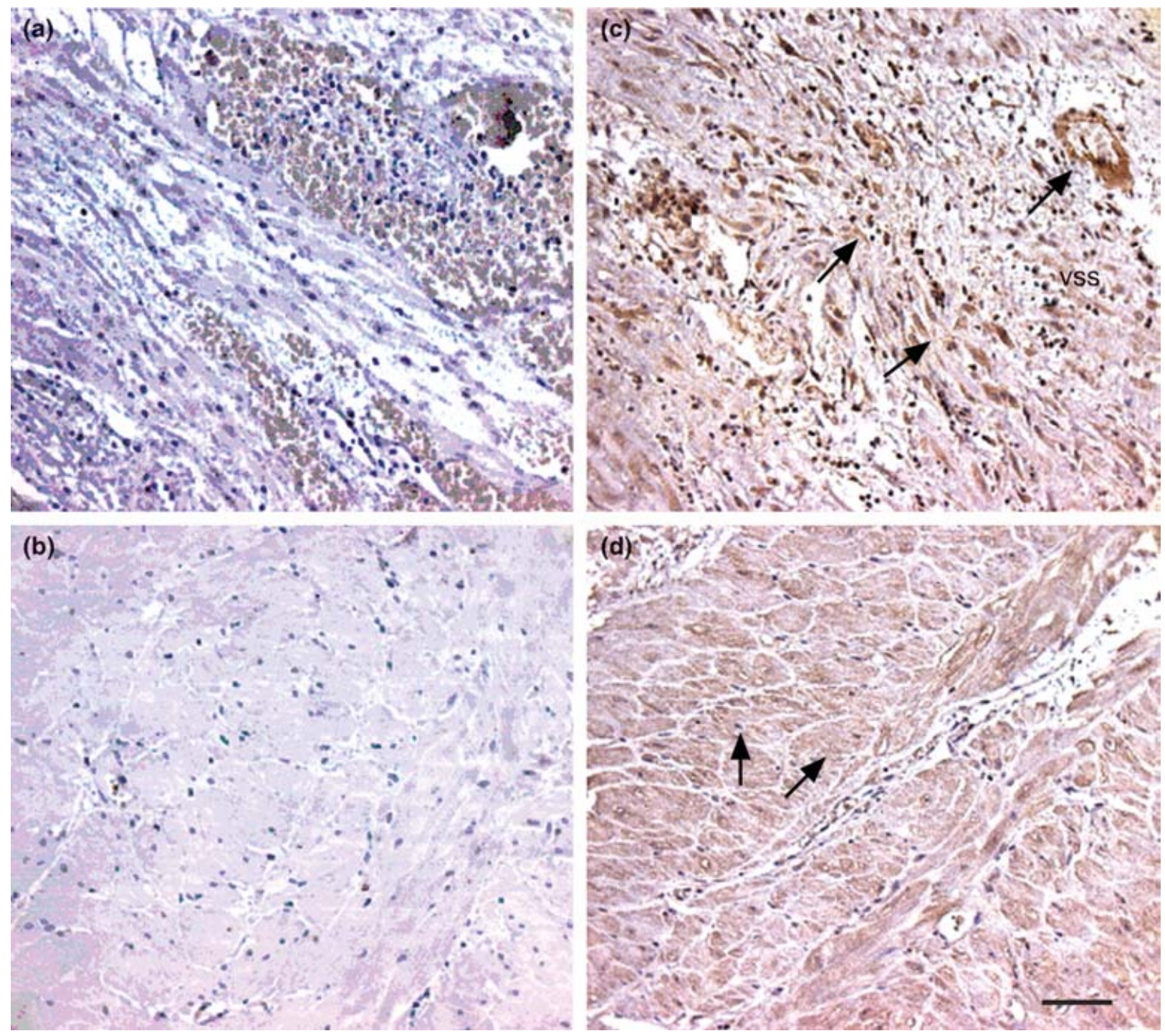

Fig. 1. Immunostaining of formalin-fixed human myometrium demonstrates control sections of (a) term pregnant without labour and (b) term pregnant with labour incubated with mouse lgG. Positive staining for the $\alpha$ subunit of the large-conductance calciumactivated potassium $\left(\mathrm{BK}_{\mathrm{Ca}}\right.$ ) channel (arrow) in (c) term without labour and (d) term pregnant with labour, is clearly observed. The staining intensity appears similar between both groups. Smooth muscle cells lining blood vessels are also positively stained for $\alpha$ subunit protein (c). VSS: blood vessels. Scale bar represents $50 \mu \mathrm{m}$.

analysis was performed using the statistics program SPSS for Windows version 11.0 (SPSS Inc., Chicago, IL). All data are presented as median and interquartile ranges. Differences between groups were assessed using the Mann-Whitney $U$ test. A two-tailed $P$ value $<0.05$ was considered to be statistically significant.

\section{Results}

\section{Immunocytochemistry}

Myometrial sections from pregnant women at term who were and were not undergoing labour demonstrate that myometrial cells are spindle shaped with oval or spindle-shaped nuclei (Fig. 1). The cells are separated by oedema of the extracellular matrix.

Positive immunoreactivity for the $\alpha$ subunit of $\mathrm{BK}_{\mathrm{Ca}}$ channels in myometrial cells from pregnant women at term who were or were not undergoing labour was detected by immunohistochemistry (Fig. 1c,d). The expression of $\mathrm{BK}_{\mathrm{Ca}}$ channel $\alpha$ subunit was predominantly localized at the plasma membrane and evenly dispersed throughout the cytosol (Fig. 1c,d). This result is in contrast to the lack of signal in the control sections in which mouse IgG was applied instead of primary antibody (Fig. 1a,b). Subjective assessment of the sections indicated that similar amounts of $\alpha$ subunit protein are present in pregnant women who were or were not 
(a)

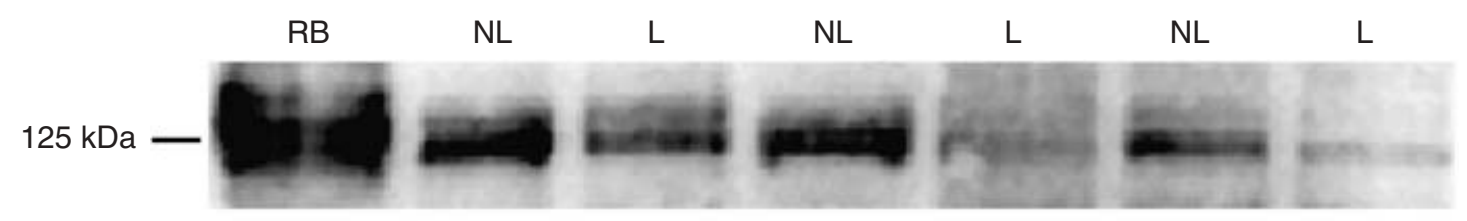

(b)

L NL

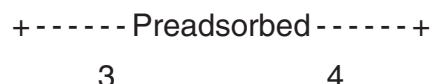

12

3

4

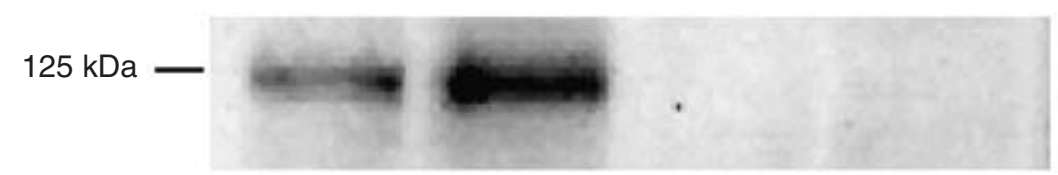

Fig. 2. Immunodetection of large-conductance calcium-activated potassium $\left(\mathrm{BK}_{\mathrm{Ca}}\right)$ channel $\alpha$ subunit protein (a) in human myometrium and rat brain demonstrates a protein band of approximately $125 \mathrm{kDa}$; (b) the protein band corresponding to the $\mathrm{BK}_{\mathrm{Ca}}$ channel of the $\alpha$ subunit (lanes 1 and 2) is absent after preadsorption with fivefold excess antigenic peptide (lanes 3 and 4). RB: rat brain; NL: non-labour; L: labour.

undergoing labour (Fig. 1c,d). Intense immunoreactivity in the myometrium before and after the onset of labour was observed with the anti- $\alpha$-actin antibody (data not shown).

\section{Western blot analysis}

Myometrium from 26 pregnant women at term who were not undergoing labour, and 25 pregnant women at term who were undergoing labour was analysed for protein expression of the $\mathrm{BK}_{\mathrm{Ca}}$ channel $\alpha$ subunit. Equal loading of proteins was confirmed by Ponceau $\mathrm{S}$ staining. A single protein band of approximately $125 \mathrm{kDa}$ corresponding to the $\mathrm{BK}_{\mathrm{Ca}}$ channel $\alpha$ subunit was observed in these two groups (Fig. 2a). This band was reproducibly and consistently detected after several experiments using different samples. The $125 \mathrm{kDa}$ band is similar to that detected in rat brain positive control samples, albeit of a slightly lower molecular mass (Fig. 2a). Immunoreactivity was abolished when anti-

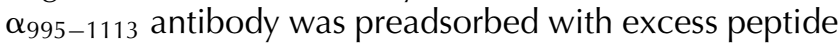
against which the antibody was raised (Fig. 2b), thereby confirming the specificity of the antibody. Duplet bands corresponding to the size of the $\mathrm{BK}_{\mathrm{Ca}}$ channel $\alpha$ subunit were present in some membrane samples (Fig. 2a).

The expression of $\mathrm{BK}_{\mathrm{Ca}}$ channel $\alpha$ subunit in rat brain was used as a reference against which expression in the human myometrium was compared. The protein bands of the $\mathrm{BK}_{\mathrm{Ca}}$ channel $\alpha$ subunit are compared for pregnant women at term who were and were not undergoing labour. The medians (interquartile) of $\alpha$ subunit $\mathrm{BK}_{\mathrm{Ca}}$ channel expression were $30.6 \%(20.3,43.9)$ and $15.7 \%$ $(11.3,22.4)$ in pregnant women at term who were not undergoing labour, and pregnant women at term who were undergoing labour, respectively (Fig. 3). The

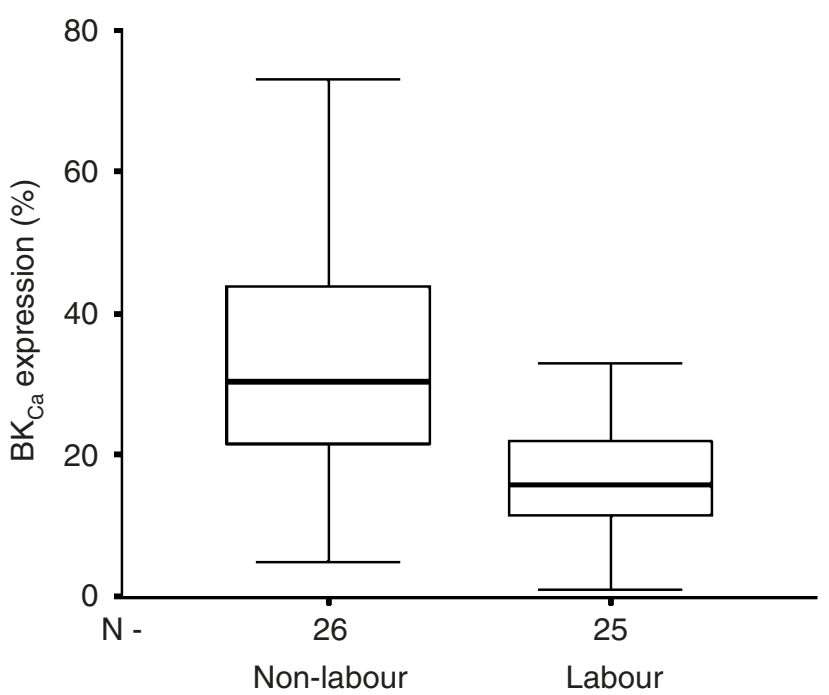

Fig. 3. Quantitation of large-conductance calcium-activated potassium $\left(\mathrm{BK}_{\mathrm{Ca}}\right)$ channel $\alpha$ subunit protein expression in myometrium of pregnant women at term who were or were not undergoing labour. Values are expressed as percentages relative to rat brain membrane protein. The box and whisker plot represents the median values with $50 \%$ of all data falling within the box.

expression of $\alpha$ subunit $\mathrm{BK}_{\mathrm{Ca}}$ channel protein in the group of women who were not in labour was significantly higher than that in the group of women who were undergoing labour $(P<0.01)$.

\section{Discussion}

The uterus undergoes marked changes in size and contractility during pregnancy. Membrane receptors and ion 
channels are probably involved in these processes. $\mathrm{BK}_{\mathrm{Ca}}$ channels are abundant in myometrial cells and have an important role in the regulation of human myometrial cell membrane potential (Anwer et al., 1993; Khan et al., 1993; Perez et al., 1993). However, the relationship between the $\mathrm{BK}_{\mathrm{Ca}}$ channel and uterine contractions is not clearly understood. In the present study, a monoclonal antibody was used that was specific to the $\alpha$ subunit to compare the distribution and difference of $\mathrm{BK}_{\mathrm{Ca}}$ channel $\alpha$ subunit protein expression in human myometrium between pregnant women at term who were and were not undergoing labour. The findings of the present study indicate positive immunoreactivity for the $\mathrm{BK}_{\mathrm{Ca}} \alpha$ subunit at the plasma membrane and cytosol of smooth muscle cells in the myometrium of pregnant women at term who were and were not undergoing labour (Fig. 1c,d). Although the intensity of immunoreactivity is apparently similar between these two groups, this does not represent accurately the amount of $\mathrm{BK}_{\mathrm{Ca}}$ channel $\alpha$ subunit protein due to the inherent limitations of immunohistochemistry as a quantitative tool. By running parallel western blotting experiments with the same anti-BK $\mathrm{Ca}_{\mathrm{Ca}}$ channel $\alpha$ subunit monoclonal antibody, the presence of a $125 \mathrm{kDa}$ band has been demonstrated in myometrium of pregnant women at term who were or were not undergoing labour. The molecular mass of this band correlates well with the $\mathrm{BK}_{\mathrm{Ca}}$ channel $\alpha$ subunit in positive controls of rat brain. A reduction of approximately $50 \%$ was observed in expression of $\alpha$ subunit of term labour compared with term non-labour samples.

Evidence regarding the expression of $\mathrm{BK}_{\mathrm{Ca}}$ channel $\alpha$ subunit protein in the myometrium to date has proven inconclusive (Song et al., 1999; Benkusky et al., 2000; Zhou et al., 2000). It was reported by Song et al. (1999) that the expression of the $\alpha$ subunit of the $\mathrm{BK}_{\mathrm{Ca}}$ channel is decreased by $60 \%$ in the myometrium of pregnant rats at term compared with expression in non-pregnant rats (Song et al., 1999). In contrast, the expression of $\mathrm{BK}_{\mathrm{Ca}}$ channel $\alpha$ subunit increases in mouse myometrium throughout pregnancy and decreases postpartum (Benkusky et al., 2000). Furthermore, BK $\mathrm{Ca}$ channel $\alpha$ subunit expression remains virtually unchanged among pregnant, non-labouring and nonpregnant human myometrium (Zhou et al., 2000). However, no study to date appears to have examined $\mathrm{BK}_{\mathrm{Ca}}$ channel $\alpha$ subunit localization and expression between women who were or were not in labour with adequate power.

The results of the present study indicate that the removal of myometrial quiescence that leads to labour may arise as a consequence of decreased amounts of $\mathrm{BK}_{\mathrm{Ca}}$ channel $\alpha$ subunit protein in myometrium. These findings are compatible with those of Song et al. (1999) for rat myometrium. Although Benkusky et al. (2000) demonstrated that the expression of $\mathrm{BK}_{\mathrm{Ca}}$ channel $\alpha$ subunit in mouse myometrium was upregulated at term before the onset of labour, their electrophysiological recordings revealed a significant reduction of myometrial $\mathrm{BK}_{\mathrm{Ca}}$ channel whole-cell current in termpregnant compared with that of non-pregnant animals. The inconsistent findings reported for expression of $\mathrm{BK}_{\mathrm{Ca}}$ channel $\alpha$ subunit protein found with gestation may reflect interspecies variation relating to pregnancy (for example litter size, initiation of labour) as well as the use of different primary antibodies directed at the $\mathrm{C}$ terminus of the $\alpha$ subunit of the channel. The contribution of the $\mathrm{BK}_{\mathrm{Ca}}$ channel itself in regulating uterine activity may also differ in a species-specific manner.

Electrophysiological studies have demonstrated that outward $\mathrm{K}^{+}$currents in rat myometrium have reduced calcium sensitivity near term (Wang et al., 1998). Furthermore, Khan et al. (1993) showed that $\mathrm{BK}_{\mathrm{Ca}}$ channels in human myometrium lose their calcium and voltage dependence after the onset of labour. These findings indicate that $\mathrm{BK}_{\mathrm{Ca}}$ channel protein may be modified during gestation and before the onset of labour. Furthermore, Wang et al. (1998) reported that functionally important shifts in potassium channel expression occur that would probably promote uterine excitability. Thus there is an apparent shift at term towards increased expression of small-conductance delayed rectifier potassium channels together with a reduced $\mathrm{Ca}^{2+}$ sensitivity and a positive shift in the activation of $\mathrm{BK}_{\mathrm{Ca}}$ channels. In addition, the contribution of $\mathrm{BK}_{\mathrm{Ca}}$ channels to the total outward current was reduced by approximately $10 \%$ in late-pregnancy myocytes compared with non-pregnant myocytes.

Doublet bands at the level corresponding to the $\alpha$ subunit $\mathrm{BK}_{\mathrm{Ca}}$ channel, which have also been demonstrated in rat and mouse myometrium by Song et al. (1999) and Benkusky et al. (2000), were observed. These bands may represent different isoforms of the $\mathrm{BK}_{\mathrm{Ca}}$ channel $\alpha$ subunit protein or result from post-translational protein modifications. The differential sensitivity of $\mathrm{BK}_{\mathrm{Ca}}$ channels to $\mathrm{Ca}^{2+}$ and voltage has been attributed to the presence of $\mathrm{BK}_{\mathrm{Ca}}$ channel isoforms in neuronal and cochlear tissues (Tseng-Crank et al., 1994; Rosenblatt et al., 1997). However, the functional impact of these $\mathrm{BK}_{\mathrm{Ca}}$ channel isoforms on uterine contractions has not been demonstrated.

In conclusion, the distribution of the $\mathrm{BK}_{\mathrm{Ca}}$ channel $\alpha$ subunit has been directly localized in the myometrial cells of pregnant women who are and are not undergoing labour. The downregulation of $\mathrm{BK}_{\mathrm{Ca}}$ channel $\alpha$ subunit protein noted following parturition may contribute, in part, to the enhanced myometrial contractility observed with the onset of labour.

The authors thank the midwives, clinicians and patients at Derby City General Hospital for their assistance and participation. B. Matharoo-Ball was supported by Tommy's, the Baby Charity (registered charity 1060508). 


\section{References}

American College of Obstetricians and Gynecologists (2001) Assessment of risk factors for preterm birth Obstetrics and Gynecology $\mathbf{9 8}$ 709-716

Anwer K, Oberti C, Perez GJ, Perez-Reyes N, McDougall JK, Monga M, Sanborn BM, Stefani E and Toro L (1993) Calcium-activated K channels as modulators of human myometrial contractile activity American Journal of Physiology 265 C976-C985

Benkusky NA, Fergus DJ, Zucchero TM and England SK (2000) Regulation of the $\mathrm{Ca}^{2+}$-sensitive domains of the maxi-K channel in the mouse myometrium during gestation Journal of Biological Chemistry $\mathbf{2 7 5}$ $27712-27719$

Erulkar SD, Ludmer J, Ger B and Nori RD (1993) Expression of different potassium channels in cells isolated from human myometrium and leiomyomas American Journal of Obstetrics and Gynecology $\mathbf{1 6 8}$ 1623-1639

Jeyabalan A and Caritis SN (2002) Pharmacologic inhibition of preterm labor Clinical Obstetrics and Gynecology 45 99-113

Khan RN, Smith SK, Morrison JJ and Ashford MLJ (1993) Properties of large conductance potassium channels in human myometrium during pregnancy and labour Philosophical Transactions of the Royal Society of London Series B Biological Science 251 9-15

Khan RN, Smith SK, Morrison JJ and Ashford MLJ (1997) Calciumdependence and pharmacology of large-conductance potassium channels in nonlabour and labour uterine myocytes American Journal of Physiology 273 C1721-C1731

Khan RN, Smith SK, Morrison JJ and Ashford MLJ (1998) Activation of large-conductance potassium channels in pregnant human myometrium by pinacidil American Journal of Obstetrics and Gynecology 178 1027-1034
Perez GJ, Toro L, Erulkar SD and Stefani E (1993) Characterisation of large-conductance, calcium-activated potassium channels from human myometrium American Journal of Obstetrics and Gynecology 168 652-660

Rosenblatt KP, Sun ZP, Heller S and Hudspeth AJ (1997) Distribution of $\mathrm{Ca}^{2+}$-activated $\mathrm{K}^{+}$channel isoforms along the tonotopic gradient of the chicken's cochlea Neuron 19 1061-1075

Song M, Zhu N, Olcese R, Barila B, Toro L and Stefani E (1999) Hormonal control of protein expression and mRNA levels of MaxiK channel alpha subunit in myometrium FEBS Letters $\mathbf{4 6 0}$ 427-432

Tseng-Crank J, Foster CD, Krause JD, Mertz R, Godinot N, DiChiara TJ and Reinhart PH (1994) Cloning, expression, and distribution of functionally distinct $\mathrm{Ca}^{(2+)}$-activated $\mathrm{K}^{+}$channel isoforms from human brain Neuron 13, 1315-1330

Wang SY, Yoshino M, Sui JL, Wakui M, Kao PN and Kao CY(1998) Potassium currents in freshly dissociated uterine myocytes from nonpregnant and late-pregnant rats Journal of General Physiology 112 737-756

Wanner SG, Koch RO, Koschak A, Trieb M, Garcia ML, Kaczorowski G] and Knaus H-G (1999) High-conductance calcium-activated potassium channels in rat brain: pharmacology, distribution and subunit composition Biochemistry 38 5392-5400

Zhou XB, Wang GX, Ruth P, Huneke B and Korth M (2000) BK(Ca) channel activation by membrane-associated CGMP kinase may contribute to uterine quiescence in pregnancy American Journal of Physiology Cell Physiology 279 C1751-C1759

Received 27 January 2003

First decision 12 March 2003.

Revised manuscript received 19 March 2003.

Accepted 21 March 2003. 